\title{
Financial performance of PT. Garuda Indonesia Tbk period 2018-2019
}

\author{
Muhammad Ichsan Siregar $^{1^{*}}$, H. Abdullah Saggaf ${ }^{2}$, Rifani Akbar Sulbahri ${ }^{3}$, Mohammad Aryo \\ Arifin $^{4}$, Muhammad Hidayat ${ }^{5}$, Firmansyah Arifin ${ }^{6}$ \\ Universitas Sriwijaya ${ }^{1,2,5}$, Universitas Tridinanti ${ }^{3,6}$, Universitas PGRI ${ }^{4}$ \\ ichsansiregar@fe.unsri.ac.id ${ }^{1}$, abdullahsaggaf@fe.unsri.ac.id ${ }^{2}$,rifaniakbar.sulbahri@univ- \\ tridinanti.ac.id ${ }^{3}$,aryoarifin@univpgri-palembang.ac.id ${ }^{4}$, muhammadhidayat@fe.unsri.ac.id ${ }^{5}$, \\ firmansyah.arifin@ymail.com ${ }^{6}$
}

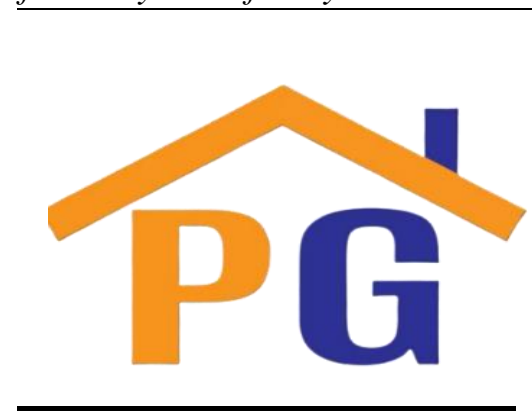

Riwayat Artikel

Diterima pada 6 November 2020

Revisi 1 pada 9 November 2020

Revisi 2 pada 14 Desember 2020

Disetujui pada 16 Desember 2020

\begin{abstract}
Purpose: This study aims to determine the health level of the financial report of the performance of PT. Garuda Indonesia Tbk with the financial ratios of State-Owned Enterprises for the period 2018-2019.

Research methodology: Researchers took the statement of financial position of profit and loss as a tool to assess the soundness of the financial performance of PT. Garuda Indonesia Tbk.
\end{abstract}

Results: In accordance with Decree: $K E P-100$ / KBU / 2002, as a result, In 2018 PT. Garuda Indonesia Tbk was declared unhealthy with a "CCC" assessment in which the total score obtained from the financial aspect was 21 with a standard assessment of $20 \leq$ TS $\leq=30$ with the category of assessment "CCC". Meanwhile in 2019, PT. Garuda Indonesia Tbk was declared unhealthy with a "BB" rating in which the total score obtained from the financial aspect is 45 with a standard assessment of $40 \leq \mathrm{TS} \leq=50$ with the category of rating "BB".

Limitations: Limitations of this research are: this study only took 2 years in the period 2018-2019, the sample taken in this study is a statement of financial position and income.

Contribution: This study gives a contribution to policy input from the financial performance of PT. Garuda Indonesia Tbk

Keywords: Financial, Performance, Ratios, Financial statements

How to cite: Siregar, M. I., Saggaf, H., Sulbahri, R. A., Arifin, M. A., Hidayat. M., Arifin, F. (2020). Financial performance of PT. Garuda Indonesia Tbk period 2018-2019. Jurnal Akuntansi, Keuangan, dan Manajemen, 1(4), 315-324.

\section{Introduction}

Analysis of the company's financial statements basically knows the level of profitability, liquidity, solvency and risk level or the health level of a company. Financial analysis that includes financial ratio analysis, weakness and strength analysis in the financial sector is very helpful in assessing past management achievements and future prospects. The increasingly competitive development of the business world in Indonesia requires every company to manage and implement company management to be more professional. The development of the business world is due to the emergence of a large number of competitors in the business world, both domestic and foreign competitors. Every company continues to strive to improve company performance for the better, in order to maintain the existence and effectiveness of the company in better company performance in the future.

As an example, the State-Owned Airline Company Garuda Indonesia (GIAA) has recently been in the public spotlight because its presentation of the 2018 financial report does not comply with accounting standards. Garuda finally restated its 2018 financial statements. In the restatement of the financial statements Garuda recorded has a loss, not a profit as previously reported. Disclosure of 
information on the Indonesia Stock Exchange (IDX) after an adjustment was made the airline lost US \$ 175 million or the equivalent of Rp. 2.45 trillion (exchange rate of Rp. 14,004/US \$). The financial report performance of PT Garuda Indonesia, Tbk which managed to book a net profit of US \$ 809 thousand in 2018 is inversely proportional to 2017 which lost US \$ 216.58 million resulting in a polemic (cnnindonesia.com, 2019).

Financial reports play an important role for companies and investors in providing an overview of the condition of the company's performance whether in a healthy or unhealthy condition. The development over time and the extent to which the company's goals have been achieved can be shown in the company's financial statements $($ Fahmi, 2013) $k$. Hery (2015), financial ratio analysis is used to determine the relationship between certain items in the statement of financial position and income statement.

Kasmir (2015:104), the ratio used to assess financial performance are liquidity ratio, solvency ratio, activity ratio and profitability ratio. Munawir (2010:36) there are two analysis methods used by every financial statement analyzer, namely horizontal analysis and vertical analysis. Horizontal (Dynamic) analysis is an analysis that is done by comparing financial reports for several periods. From the results of this analysis, it will be seen that the company's development from one period to another. Vertical Analysis (Static) is an analysis carried out on only one financial reporting period. This analysis is carried out between existing items in one period. The information is obtained only for one period and there is no known development from period to period. Kasmir (2015:118) to minimize the risk of errors in making financial ratios, a precautionary principle is needed at least with this precautionary action can help cover the weaknesses of these financial ratios.

Harahap (2010: 298) this technique also has several limitations that must be realized when using it so that we are not mistaken in its use. The limitations of the ratio analysis are difficulty in choosing the right ratio that can be used for the benefit of the wearer; the limitations of accounting or financial reporting are also the limitations of this technique, such as: the material for calculating the ratio or financial report contains a lot of estimates and judgments that can be judged biased or subjective, the value contained in the financial statements and the ratio is the cost, not the market price, classification in financial statements can have an impact on the ratio figures, the recording methods described in the accounting standards are applicable different by different companies; if the data for calculating the ratio is not available, it will be difficult to calculate the ratio; it will be difficult if the available data is out of sync; And companies compared may not use the same accounting techniques and standards. Therefore, if a comparison is made it can lead to errors.

Based on the background of the above problems, this study aims to determine the financial performance of PT Garuda Indonesia Tbk for the period 2018-2019 using financial ratio analysis. The objectives and benefits of financial statement analysis are Kasmir (2015:68) to find out the company's financial position in a certain period both assets, liabilities, capital, and business results that have been achieved for several periods to find out what weaknesses are to be deficient in the company, to find out its strengths to find out what improvement steps need to be taken in the future related to the current financial position of the company, to assess future management performance whether it needs refreshment or not because it is considered successful or failed, and can also be used as a comparison with similar companies about the results they achieved. Thus, based on the background described above, this study aims to examine the financial performance of PT Garuda Indonesia, Tbk for the period 2018-2019.

\section{Literature review}

An analysis is carried out to see the extent to which the company has implemented its performance using financial implementation rules correctly (Fahmi, 2016). Measurement of financial performance is very important as a suggestion in order to improve the company's operational activities. With improved performance it is expected that the company can experience better financial growth and can also compete with other companies through efficiency and ownership.

According to Sucipto (2003), financial performance is to assess certain metrics that can measure the effectiveness of profit production by an agency or corporation. Measurement of financial performance is carried out simultaneously with the analysis process. Financial performance analysis is a critical financial review process, including reviewing financial data, calculating, measuring, and presenting solutions to financial problems in a certain period (Harmono, 2014). 
According to Mulyadi (2001) performance appraisal is the periodic determination of affective operations of an organization, parts of the organization and its employees based on goals, standards and predefined criteria. Company performance is a generic word for describes the success or success of a company. Good performance shows that the company is well managed. In operating the business world, the company can work formulated as work results obtained from activities or operations carried out by company over a certain period of time, and profit is one of the important benchmarks company performance appraisal (financial accounting standards, 2001).

According to Munawir (2002) the objectives of assessing company performance are to determine the level of liquidity, the company fulfills its financial obligations when billed; to determine the level of solvency, namely the company's ability to fulfill profit obligation if the company is liquidated both obligations short-term and long-term finance; to determine the level of profitability, which is a company's ability to generate profit for the specified period, to determine business stability, namely the company's ability to perform business steadily and consider the company to pay dividends regularly.

According to zaki baridwan in his book intermediate accounting (2004) understanding financial statements are: a summary of the financial transactions that occurred during one the relevant financial year. Financial reports are basically the result of the accounting process which can be used as a tool to communicate between financial data or an activity companies with parties with an interest in the company's data or activities.

According to Munawir (2004), Based on the data source, the ratio number can be divided into balance Sheet ratios (Balance Sheet Ratios) that fall into this category are all ratios for which all data is taken or sourced on the balance sheet, eg current ratio, acid test ratio; income Statement Ratios are numbers the ratio in which all data is drawn from the Income Statement Loss, for example gross profit margin, net operating margin, operating ratio and so on; interstatement ratios are all figures of the ratio that is compilation of data based on the balance sheet and other data from the income repor Loss, for example, inventory turnover, level account receivable turn over, sales to inventory, sales to fixed assets and so on.

Jensen and Meckling (1986) argue that debt creates pressure for managers to work hard and, it will have an impact on increasing company productivity. Debt in Agency Theory becomes the control system of corporate governance indirectly to prevent top management's moral hazard actions, thus inhibiting top management's tendency to allocate cash flows in an inefficient fashion. Agency theory suggests that the relationship between corporate-level and country-level governance mechanisms can depend on contextual factors such as financial development or corporate debt needs, so agency theory has become a major concern of the relationship between managers and shareholders (Jensen and Meckling (1986). One of the key principles of the agency theory is that different main and agent priorities can lead to conflict, as corporate managers prefer to follow personal objectives, which can result in managers concentrating on projects and company investments that produce high returns in the short term instead of optimizing shareholder welfare through investment in sustainable long-term projects.

The concept of GCG arises in relation to the principal-agency theory, namely to avoid conflicts between the principal and his agent. Conflicts arise because these differences in interests must be managed properly so as not to cause harm to the parties. Agency theory emphasizes the importance of company owners (shareholders) handing over the management of the company to experts (agents) who better understand how to run the company (Adrian, 2011).

Referring to agency theory, public accountability is that the agent is obliged to make all the actions and activities of the agent accountable to the principal, who has the right and the authority for keeping the principal accountable. (Haryanto, Sahmuddin, Arifuddin, 2007).

The financial management perspective for each company has different policies according to the goals and interests of the company. (Myers, 1984) in Pecking Order Theory which states that companies managing capital structure funding will initially prefer retained earnings then debt, then to equity financing as the final option for capital structure funding. According to (Myers, 1984) companies tend to choose internal funding over external funding. But when external funding is needed, companies prefer debt over equity because of the ease and low cost of debt over funding through equity. External funding of companies with debt is also based on various reasons.In Pecking 
Order Theory, financial deficits encourage companies to use external financing with debt (Frank and Goyal, 2003).

According to (Modigliani and Miller, 1963) a company in a deficit condition will limit tax payments so as to motivate the company to use debt financing. Therefore, in the pecking order theory, debt is used when the company is in financial difficulties, on the other hand, if the company's finances are in very good condition, the company will prefer internal funding sources.In contrast to the viewpoint, the Static trade-off theory generally assumes that large companies having large debts are interpreted as having a lower risk of default because they are considered mature companies. So the static trade-off theory predicts leverage and firm size have a positive relationship. So that the company must have more debt because it is considered a surplus in obtaining opportunities, companies that generate higher profits relatively take the opportunity as an investment that will increase profits by being a solution to the problem of cash flow (Jensen, 1986).

Some researchers have different views, such as Myers (1984) and Fama and French (2002), in trade off Theory, they consider the lack of a positive correlation between profit and debt as a problem. Companies that have large management will also have large debts. Strengthened by relationships The quality of the company has a positive impact on company value according to Lee and Yeo (2016) company size, growth opportunities, external funding requirements, asset tangibility, and cross-listing status are factor that influences corporate governance in general.

From several differences of opinion, through debt analysis, it is considered to be one of the conveniences of external funding, so that almost all companies have debts with various assumptions in the use of debt. In managing cash flow, whether it is a surplus or a deficit, it will have an impact on the use of debt in managing cash flow, which has been considered a behavior that has the potential to grow or reduce the opportunities faced by the company (Jensen, 1986). Debt is considered as additional energy for cash flow in facing company challenges or opportunities for management, while for shareholders, external funding through high debt is a spur for company management to be able to improve company performance in order to avoid the risk of default to make the best decisions for the company in investment (Jensen, 1993). The ease of debt is so tempting for companies, one of which is the low interest costs when compared to the larger share capital issuance costs.

Attribution theory studies how a person processes interpret an event, learn how a person interpret the reasons or causes of their behavior (Luthans, 1998). This theory developed by Heider (1958) who argued that behavior a person is determined by a combination of internal and external forces. Behavior caused by these internal forces is believed comes from within the individual's own person. An example of internal strength it is ability, knowledge, and effort.

Ajzen first coined the principle of reasoned action in 1980 (Jogiyanto, 2007). This theory is structured on the simple premise that people are aware of and considerate available knowledge. In this TRA, Ajzen (1980) stated that intention someone to do a behavior determines will be done or not do the behavior. Furthermore, Ajzen stated that intention doing or not doing certain behavior is influenced by two determinants basic, the first is related to attitudes (attitude towards behavior) and the other deals with social influences, namely subjective norms.

Theory of Planned Behavior (TPB) is a further development from TRA. Ajzen (1988) adds constructs that are not yet in TRA, namely perceived behavioral control. Construct this is added in an effort to understand the limitations that individuals have in order to perform certain behaviors (Chau, et al., 1999). In other words, do or not do a behavior is not only determined by mere subjective attitudes and norms, but also individual perceptions of control what he can do that stems from his belief in control control beliefs.

Akerlof's (1970) thought was developed by Spence (1973) in basic equilibrium signaling model. A labor market (employment market) diagram by Spence (1973) indicates that businesses with strong performance (higher performance) are using financial information to relay signals to the market. Spence (1973) has also found that the expense of bad news signals is greater than good news, and that bad news is not reliable for companies. This allows management to reveal private information to minimize asymmetry of information, in the expectation that a positive signal (good news) about the success of the company would be sent to the market.

The investor would like to see the release of the information a positive indication, and the market would then respond to this by changing the trading volume of shares (Suwardjono, 2010). Financial reports are one of the forms of information that the organization may give a signal to parties 
outside the company. Information disclosed in financial statements can be in the form of information accounting, namely information related to financial reports as well information that is not related to financial statements.

Signal (signal) is an action taken by the management of a company to provide guidance to investors on how management assesses the prospects of the company. The possibility of information asymmetry between company management and interested parties encourages management to provide a signal to interested parties to reduce the information asymmetry (Brigham and Houston, 2014). Both investors and managers have the same information about the prospects for the company. Information held by both investors and managers is referred to as symmetrical information. Symmetrical information ensures that investors and management have the same information on the prospects of the business. Managers actually have more insight than external investors. The better information a manager has than an outside investor is often referred to as asymmetric information. Asymmetric information is a condition in which managers have different (meaning better) information about the business than investors' prospects. So there are two situations, namely, a situation in which company managers know that the prospect will be very profitable and another situation in which company managers know that the future looks unfavorable. (Brigham and Houston, 2014).

Signaling theory explains why businesses are urged to notify the business externally of their financial reporting. The incentive for companies to provide information is because they exist asymmetry of information between the company and external parties. External parties then assesses the firm as a function of its signaling mechanism different. Lack of outside information about the company cause them to protect themselves by giving that price low for the company, and possibly other external parties who are not have the same perception of information about the value of all firms. This view will be detrimental to companies that have conditions better because external parties will rate the company lower than that should be and vice versa (Taufiq, 2016).

Stakeholder theory explains that entities are not only operating for their own interests, but must be able to provide benefits for their stakeholders. Business continuity will also be influenced by the presence of stakeholders. So that the entity needs efforts to fulfill stakeholder desires in order to get support in the form of economic resources for the entity. Gray, Kouhy, and Adams (1995) stated that the sustainability of the enterprise depends on stakeholder support and support must be pursued in order that the activities of the enterprise can be sought. The stronger the stakeholders, the higher the commitment of the organization to adapt. This is what underlies the differences in how companies behave towards one stakeholder and another.

\section{Research methodology}

According to Sugiyono (2016:2) the research method is defined as a scientific way to obtain data with certain goals and finances, the scientific way means that the researcher's activities are based on scientific characteristics, namely rational, empirical and systematic. The research method used by the writer is quantitative descriptive method. According to Wiratna Sujarweni (2014:65), Population is the total number consisting of objects or subjects that have certain characteristics and qualities that are determined by the researcher to be investigated and then draw conclusions. The population in this study is the financial statements of the State Owned Enterprises PT. Garuda Indonesia Tbk. According to Wiratna Sujarweni (2014:65), sample is part of a number of characteristics possessed by the population used for research. Researchers take statements of financial position (balance sheet) and profit and loss for the period 2018-2019.

Data collection techniques in this study contained secondary data. The data analysis method used in this research is quantitative analysis. To assess financial performance, it is seen from several indicators issued by Decree of the Minister of SOE concerning the assessment of the soundness level of State-Owned Enterprises and financial ratios.

Table 1

\begin{tabular}{|l|c|c|}
\hline \multirow{2}{*}{ Indicator } & \multicolumn{2}{|c|}{ Weight } \\
\cline { 2 - 3 } & Infra & Non Infra \\
\hline 1. Rewards to shareholders & 15 & 20 \\
\hline 2. Return on investment & 10 & 15 \\
\hline
\end{tabular}




\begin{tabular}{|l|c|c|}
\hline 3. Cash ratio & 3 & 5 \\
\hline 4. Smooth ratio & 4 & 5 \\
\hline 5. Collection priods & 4 & 5 \\
\hline 6. Inventory turnover & 4 & 5 \\
\hline 7. Turnover of total assets & 4 & 5 \\
\hline $\begin{array}{l}\text { 8. Own capital ratio to total } \\
\text { assets }\end{array}$ & 6 & 10 \\
\hline $\begin{array}{l}\text { Total Weight } \\
\text { Soe }\end{array}$ & 50 & 70 \\
\hline
\end{tabular}

Source: Decree of the Minister of SOE

Table 2

\begin{tabular}{|c|l|l|l|}
\hline \multirow{4}{*}{ Criteria } & \multicolumn{3}{|c|}{ Assessment of the health level of SOE } \\
\cline { 2 - 4 } & \multicolumn{1}{|c|}{ Healthy } & \multicolumn{1}{|c|}{ Unwell } & \multicolumn{1}{c|}{ Not healthy } \\
\cline { 2 - 4 } & AAA Total TS $\geq 95$ & BBB $50 \leq \mathrm{TS} \leq=65$ & CCC $20 \leq \mathrm{TS} \leq=30$ \\
\cline { 2 - 4 } & AA $80 \leq \mathrm{TS} \leq=95$ & BB $40 \leq \mathrm{TS} \leq=50$ & $\mathrm{CC} 10 \leq \mathrm{TS} \leq=20$ \\
\cline { 2 - 4 } & A $65 \leq \mathrm{TS} \leq=80$ & $\mathrm{~B} 30 \leq \mathrm{TS} \leq=40$ & $\mathrm{C} \leq \mathrm{TS} \leq=10$ \\
\hline
\end{tabular}

Source: Decree of the Minister of SOE

Table 3

\begin{tabular}{|c|c|c|c|c|}
\hline $\begin{array}{l}\text { Assessment } \\
\text { Indicators }\end{array}$ & $\begin{array}{c}\text { Weight } \\
\text { of } \\
\text { Non } \\
\text { Infra }\end{array}$ & \multicolumn{3}{|c|}{$\begin{array}{l}\text { Assessment Formulas } \\
\text { Financial Ratio According to the Decree of the Minister of SOE }\end{array}$} \\
\hline \multirow[t]{3}{*}{$R O E$} & 20 & \multirow{3}{*}{ ROE } & & \multirow[b]{3}{*}{ x $100 \%$} \\
\hline & & & EAT & \\
\hline & & & Equity & \\
\hline \multirow[t]{2}{*}{$R O I$} & \multirow[t]{2}{*}{15} & \multirow[t]{2}{*}{ ROI } & EBIT+ Depreciation & \multirow[b]{2}{*}{ x $100 \%$} \\
\hline & & & Equity & \\
\hline \multirow[b]{2}{*}{ Cash Ratio } & \multirow[t]{2}{*}{5} & \multirow[b]{2}{*}{ Cash Ratio } & Cash + Bank + Short-term Securities & \multirow[b]{2}{*}{ x $100 \%$} \\
\hline & & & Current liabilities & \\
\hline \multirow{2}{*}{$\begin{array}{l}\text { Current } \\
\text { Ratio }\end{array}$} & \multirow[t]{2}{*}{5} & \multirow[t]{2}{*}{ Current Ratio } & Current assets & \multirow[t]{2}{*}{ x $100 \%$} \\
\hline & & & Current liabilities & \\
\hline \multirow{2}{*}{$\begin{array}{l}\text { Collection } \\
\text { Priods }\end{array}$} & \multirow[t]{2}{*}{5} & \multirow[t]{2}{*}{$\mathrm{CP}$} & Total Accounts Receivable & \multirow[t]{2}{*}{ x 100\% } \\
\hline & & & Total Operating Income & \\
\hline \multirow{2}{*}{$\begin{array}{l}\text { Inventory } \\
\text { Turnover }\end{array}$} & \multirow[t]{2}{*}{5} & \multirow[t]{2}{*}{ PP } & Total Inventory & \multirow[t]{2}{*}{ x $100 \%$} \\
\hline & & & Total Operating Income & \\
\hline \multirow{2}{*}{$\begin{array}{l}\text { Total Asset } \\
\text { Turnover }\end{array}$} & \multirow[t]{2}{*}{5} & \multirow[t]{2}{*}{ TATO } & Total income & \multirow[t]{2}{*}{ x $100 \%$} \\
\hline & & & Equity & \\
\hline \multirow[b]{2}{*}{$\begin{array}{l}\text { Ratio of } \\
\text { Own } \\
\text { Capital to } \\
\text { Total } \\
\text { Assets }\end{array}$} & \multirow[t]{2}{*}{10} & \multirow[t]{2}{*}{ TMS To TA } & Total Equity & \multirow[t]{2}{*}{ x 100\% } \\
\hline & & & Total Assets & \\
\hline
\end{tabular}

Source: Decree of the Minister of SOE 
4. Results and discussion

Table 4

\begin{tabular}{|c|c|c|c|c|c|c|}
\hline $\begin{array}{l}\text { Assessme } \\
\text { nt } \\
\text { Indicators }\end{array}$ & $\begin{array}{l}\text { Weight } \\
\text { of } \\
\text { Non } \\
\text { Infra }\end{array}$ & \multicolumn{3}{|c|}{$\begin{array}{c}\text { Assessment Formulas } \\
\text { Financial Ratio According to the Decree of the Minister of } \\
\text { SOE }\end{array}$} & 2018 & 2019 \\
\hline \multirow[t]{3}{*}{$R O E$} & \multirow[t]{3}{*}{20} & \multirow{3}{*}{ ROE } & & \multirow[b]{3}{*}{ x $100 \%$} & \multirow{3}{*}{$(24 \%)$} & \multirow{3}{*}{$13 \%$} \\
\hline & & & EAT & & & \\
\hline & & & Equity & & & \\
\hline \multirow[t]{2}{*}{ ROI } & \multirow[t]{2}{*}{15} & \multirow[t]{2}{*}{ ROI } & EBIT+ Depreciation & \multirow[b]{2}{*}{ x $100 \%$} & \multirow[t]{2}{*}{$(30 \%)$} & \multirow[t]{2}{*}{$7 \%$} \\
\hline & & & Equity & & & \\
\hline \multirow{2}{*}{$\begin{array}{l}\text { Cash } \\
\text { Ratio }\end{array}$} & \multirow[t]{2}{*}{5} & \multirow[t]{2}{*}{ Cash Ratio } & $\begin{array}{c}\text { Cash }+ \text { Bank }+ \text { Short-term } \\
\text { Securities }\end{array}$ & \multirow[t]{2}{*}{ x $100 \%$} & \multirow[t]{2}{*}{$52 \%$} & \multirow[t]{2}{*}{$49 \%$} \\
\hline & & & Current liabilities & & & \\
\hline \multirow{2}{*}{$\begin{array}{l}\text { Current } \\
\text { Ratio } \\
\end{array}$} & \multirow[t]{2}{*}{5} & \multirow{2}{*}{$\begin{array}{r}\text { Current } \\
\text { Ratio }\end{array}$} & Current assets & \multirow[t]{2}{*}{ x $100 \%$} & \multirow[t]{2}{*}{$37 \%$} & \multirow[t]{2}{*}{$35 \%$} \\
\hline & & & Current liabilities & & & \\
\hline \multirow{2}{*}{$\begin{array}{l}\text { Collection } \\
\text { Priods }\end{array}$} & \multirow[t]{2}{*}{5} & \multirow[t]{2}{*}{$\mathrm{CP}$} & Total Accounts Receivable & \multirow[t]{2}{*}{ x $100 \%$} & \multirow[t]{2}{*}{9 day } & \multirow[t]{2}{*}{5 day } \\
\hline & & & Total Operating Income & & & \\
\hline \multirow{2}{*}{$\begin{array}{l}\text { Inventory } \\
\text { Turnover }\end{array}$} & \multirow[t]{2}{*}{5} & \multirow[t]{2}{*}{ PP } & Total Inventory & \multirow[t]{2}{*}{ x $100 \%$} & \multirow[t]{2}{*}{4 day } & \multirow[t]{2}{*}{3 day } \\
\hline & & & Total Operating Income & & & \\
\hline Total & 5 & TATO & Total income & x $100 \%$ & & \\
\hline $\begin{array}{l}\text { Asset } \\
\text { Turnover }\end{array}$ & & & Equity & & $599 \%$ & $635 \%$ \\
\hline Ratio of & 10 & TMS to TA & Total Equity & x $100 \%$ & & \\
\hline $\begin{array}{l}\text { Own } \\
\text { Capital to } \\
\text { Total } \\
\text { Assets }\end{array}$ & & & Total Assets & & $18 \%$ & $16 \%$ \\
\hline
\end{tabular}

source: processed data, 2020

Table 5

\begin{tabular}{|l|c|c|c|}
\hline \multicolumn{1}{|c|}{ Assessment Indicators } & $\begin{array}{c}\text { Weight Non } \\
\text { Infra }\end{array}$ & 2018 & 2019 \\
\hline ROE & 20 & 0 & 18 \\
\hline ROI & 15 & 0 & 6 \\
\hline Cash Ratio & 5 & 5 & 5 \\
\hline Current Ratio & 5 & 0 & 0 \\
\hline Collection Priods & 5 & 5 & 5 \\
\hline Inventory Turnover & 5 & 5 & 5 \\
\hline Total Asset Turnover & 5 & 0 & 0 \\
\hline $\begin{array}{l}\text { Ratio of Own Capital to Total } \\
\text { Assets }\end{array}$ & 10 & 6 & 6 \\
\hline Total Rating & 70 & 21 & 45 \\
\hline
\end{tabular}

source: processed data, 2020 
Based on the classification of financial performance levels based on the Decree of the Minister of SOE in table 2. Then the results of the research are seen from the period 2018-2019. Financial Statements of PT. Garuda Indonesia Tbk uses analysis of profitability ratios, liquidity, activity and solvency in accordance with the regulations of the ministerial decree of State Owned Enterprises as follows:

1. The financial performance of PT. Garuda Indonesia Tbk in 2018

The company's overall financial performance is measured based on eight calculated indicators. From the appraiser, each indicator used to measure the financial performance of StateOwned Enterprises. According to Decree of the Minister of SOE, the company was declared unhealthy with a "CCC" assessment where the total score obtained from the financial aspect in 2018 was 21 with an assessment standard of $20 \leq \mathrm{TS} \leq=30$. In 2018 the "CCC" assessment was obtained due to a decline financial performance on the ratio of ROE, ROI, current ratio and total asset turnover. The four results of these ratios show results with values below standard or zero (0).

Agency theory suggests that the relationship between corporate-level and country-level governance mechanisms can depend on contextual factors such as financial development or corporate debt needs, so agency theory has become a major concern of the relationship between managers and shareholders (Jensen and Meckling (1986).

2. The financial performance of PT. Garuda Indonesia, Tbk in 2019

The company's overall financial performance is measured based on eight calculated indicators. From the appraiser, each indicator used to the financial performance of State-Owned Enterprises. According to Decree of the Minister of SOE, the company was declared unhealthy with a "BB" assessment where the total score obtained from the financial aspect in 2019 was 45 with an assessment standard of $40 \leq \mathrm{TS} \leq=50$. In 2019 the "BB" assessment was obtained due to decreased performance of financial ratio at current ratio and total asset turnover. Both of these ratios show results with values below the standard or zero $(0)$.

Agency theory suggests that the relationship between corporate-level and country-level governance mechanisms can depend on contextual factors such as financial development or corporate debt needs, so agency theory has become a major concern of the relationship between managers and shareholders (Jensen and Meckling (1986).

\section{Conclusion}

1. In accordance with KEP-100 / MBU / 2002 PT. Garuda Indonesia, Tbk in 2018 was declared unhealthy with a "CCC" assessment where the total score was 21 with an assessment standard of $20 \leq \mathrm{TS} \leq=30$. In 2018 the "CCC" assessment was obtained due to decreased financial performance in the ROE, ROI, current and current ratios. total asset turnover. Meanwhile, in 2019 it was declared unhealthy with a "BB" assessment where the total score was 45 with an assessment standard of $40 \leq \mathrm{TS} \leq=50$. In 2019 the "BB" assessment was obtained due to decreased financial performance in the current ratio and total asset turnover.

2. Within a period of 2 years, in 2018-2019 the assessment of the financial performance of PT. Garuda Indonesia, Tbk has experienced a decline in financial performance with a poor condition.

\section{Limitation and study forward}

Limitations of this study are:

1. This study only took 2 years in period 2018-2019.

2. The sample taken in this study is a statement of financial position and income.

\section{Further research}

1. The research period is expected to be more than 2 years.

2. The next sample taken should be not only a statement of financial position and income but also other statements of financial component

\section{Acknowledgement}

1. PT. Garuda Indonesia Tbk as an object of research.

2. All research teams: 
1. Muhammad Ichsan Siregar, SE., M.S.Ak., CSRS., CSP., CSRA

2. H. Abdullah Saggaf, SE., M.Si

3. Rifani Akbar Sulbahri, SE., M.Si., Ak., CA

4. Mohammad Aryo Arifin, SE., M.Si., Ak., CA

5. Muhammad Hidayat, SE., M.Si., Ak., CA

6. Firmansyah Arifin, SE., M.Si

\section{References}

Ajzen, Icek., \& Fishbein. (1980). Theory of reasoned action. Edisi Kesatu. (Jogiyanto, 2007)

Ajzen, I. (1988). Attitudes, personality, and behavior. Dorsey Press, Chicago.

Akerlof. (1970). The market of lemons. The MIT Press. Oxford University. Oxford.

Baridwan, Z. (2004). Intermediate accounting. Edisi Kedelapan, Yogyakarta: BPFE.

Brigham, E. F., \& Houston, J. F. (2014). Dasar-dasar manajemen keuangan. Buku 1. Edisi 11. Jakarta: Salemba Empat.

Fama, E. and K. R. French, (2002). Testing trade-off and pecking order predictions about dividends and debt. Review of Financial Studies, 15, 1-33.

Fahmi, Irham. (2013). Analisis laporan keuangan. Bandung: Alfabeta.

Frank, M. Z. and V. K. Goyal, (2003) Testing the pecking order theory of capital structure. Journal of Financial Economics, 67, 217-248.

Gray, R., Kouhy, R., \& Lavers, S. 1995. Corporate social and environmental reporting: a review of the literature and a longitudinal study of UK disclosure. Accounting, Auditing and Accountability Journal, 8(2), 47-77.

Harahap, Sofyan Syafri. (2014). Analisis kritis atas laporan keuangan. Jakarta: Grafindo Persada.

Harmono. (2014). Manajemen keuangan berbasis balanced scored. Jakarta: PT Bumi Aksara.

Haryanto, Sahmuddin, \& Arifuddin. (2007). Akuntansi Sektor Publik. Edisi Pertama: Universitas Diponegoro. Semarang.

Heider, Fritz, (1958). The psychology of Interpersonal Relations. New York: Wiley.

Hery, (2015). Analisis kinerja manajemen. Jakarta: PT Gasindo

https://www.cnnindonesia.com/ekonomi/20190430174733-92-390927/kronologi-kisruh-laporan keuangan-garuda-indonesia

Hu, P. J., P. Y. K. Chau, O. R. Liu Sheng, \& K. Y. Tam, (1999). Examining the technology acceptance model using physician acceptance of telemedicine technology. Journal of Management Information Systems, 16(2), 91-112.

Ikatan Akuntansi Indonesia (2001). Standar Akuntansi Keuangan. Salemba Empat: Jakarta.

Jensen, M. C. and W. H. Meckling, (1986). Theory of the firm: managerial behavior, agency costs and ownership structure. Journal of Financial Economics, 3, 305-360.

Jensen, Michael C. (1993). The modern industrial revolution, exit, and the failure of internal control systems. the Journal of Finance 48(3), 831-880.

Luthans. (1998). Organizational behavior. Edisi 8, Mc. Graw Hill, Singapore.

Kasmir. (2015). Analisis laporan keuangan. Jakarta: Raja Grafindo Persada

Keputusan Menteri Badan Usaha Milik Negara.KEP-100/MBU/2002

Lee, K. W., \& Yeo, G. H. H. (2016). The association between integrated reporting and firm valuation. Review of Quantitative Finance and Accounting, 47(4), 1221-1250. https://doi.org/10.1007/s11156-015-0536-y

Munawir. (2010). Analisis laporan keuangan. Yogyakarta: Liberty

Mulyadi. (2001). Balanced Scorecard: alat manajemen kontemporer untuk memperlipatgandakan kinerja keuangan perusahaan. Salemba Empat: Jakarta.

Modigliani, F., \& M. H. Miller. (1963). Corporate income taxes and the cost of capital: a correction. American Economic Review, 53, 433-443.

Myers, S. C. (1984). The capital structure puzzle. Journal of Finance, 39, 575-592.

Rachman, Taufiq, (2016). Manajemen sumber daya manusia perusahaan. Bogor: Ghalia Indonesia. 
S. Munawir (2002). Analisis informasi keuangan. Edisi Pertama, Yogyakarta: Liberty Yogya.

S. Munawir (2004). Analisis laporan keuangan. Edisi Keempat, Liberty: Yogyakarta.

Spence, Michael. (1973). Job market signaling. The Quarterly Journal of Economics, 87(3), 355-374.

Sucipto. (2003). Penilaian kinerja keuangan. Jurnal Akuntansi. Universitas Sumatera Utara. Medan.

Sugiyono. (2013). Statistika untuk penelitian. Bandung: Alfabeta

Suwardjono, (2010). Teori akuntansi: pengungkapan dan sarana interpretatif. Edisi Ketiga. BPFE, Yogyakarta.

Wiratna Sujarweni. (2014). Metode penelitian. Pustaka Baru Press. Yogyakarta

www.Idx.co.id.diakses 30 Oktober 2020

Yolla Haja O., dkk. (2019). Kinerja keuangan pada PT Garuda Indonesia (Persero) Tbk Periode 2013 -2017. Jurnal Manajemen dan Organisasi (JMO), 10(3), 182-19 